\title{
Medreligijski dialog - vsiljevanje prepričanja ali spoštovanje in sprejetje različnosti
}

\author{
Interreligious Dialogue - Imposing Beliefs \\ or Respecting and Accepting Diversity
}

Zaradi procesa globalizacije imamo občutek, da je svet postal majhen, oz. se moramo sprijazniti z dejstvom, da je tudi naše okolje "svet v malem«. To velja tudi in predvsem, ko govorimo o religijah. V Sloveniji lahko v letu 2019 najdemo predstavnike vseh največjih svetovnih religij. Pri uradu RS za verske skupnosti, ki deluje pod okriljem Ministrstva za kulturo, je registriranih in hkrati v Sloveniji dejavnih 54 verskih skupnosti. Do še pred kratkim tipična ameriška značilnost, da lahko najdemo v isti ulici drugo poleg drugega svetišča različnih religij, je postala tudi slovenska stvarnost. Če se iz središča Ljubljane sprehodimo v Šiško, bomo od katoliških, evangeličanske in pravoslavne cerkve po nekaj korakih naleteli na binkoštno, nato center za zavest Krišne, v bližini se končuje gradnja džamije, nekaj ulic naprej pa stoji mormonska kapela. Verska pluralnost je v Sloveniji postala dejstvo. Pripadniki različnih religij se ne moremo zadovoljiti zgolj s sobivanjem; hočeš nočeš se srečujemo in tudi sodelujemo. Na cesti poklepetamo z ameriškimi mormonskimi misijonarji; oranžni menihi za zavest Krišne pokličejo po telefonu, tajnik judovske skupnosti je bil študent na Teološki fakulteti, mufti Grabus pa se tudi vedno rad odzove na vabilo za predavanja ali srečanja. 
Pred leti sem se odločil, da obiščem voditelje najpomembnejših verskih skupnosti v Ljubljani. Povsod so me lepo sprejeli. Presenetilo pa me je, ko so mi nekateri izmed njih pojasnili, da so me sprejeli zgolj z namenom, da bi me spreobrnili. Resnično zanimivo izhodišče za dialog. Odgovoril sem jim, da je moj obisk izraz mojega spoštovanja do njihovega verskega prepričanja in znamenje, da katoličani sprejemamo njihovo prisotnost v slovenskem glavnem mestu. Spoštovanje in sprejemanje vernikov, ki so drugačnega verskega prepričanja, sta namreč dva temelja, ki ju je zadnji vatikanski cerkveni zbor postavil za katoliško razumevanje medreligijskega dialoga. Najprej je o njiju spregovoril Pavel VI. v okrožnici Ecclesiam suam, v kateri je papež predstavil katoliški pogled na dialog z drugimi verstvi ter kulturami. V 108. členu je zapisal: »Toda mi ne želimo odklanjati priznanja in spoštovanja duhovnim in moralnim vrednotam nekrščanskih verstev. Z njimi si želimo spodbujati ideale, ki jih vsi zagovarjamo na področju verske svobode, bratstva ljudi, svete kulture, dobrodelnosti in civilnega reda. O teh skupnih idealih je dialog z naše strani mogoč in ponudili ga bomo tam, z vsem medsebojnim spoštovanjem in vdanostjo, kjer bo dobronamerno sprejet.«V dokumentu Nostra Aetate pa so koncilski očetje zapisali, da Cerkev "z odkritosrčno spoštljivostjo gleda na one načine delovanja in življenja, na ona pravila in nauke, ki se sicer v mnogočem razlikujejo od tistega, česar se sama drži in uči, a neredko odsevajo žarek Resnice, ki razsvetljuje vse ljudi«. To so pomenljive opombe. Katoličani spoštujemo drugačno versko prepričanje in sprejemamo vernike nekatoliških in nekrščanskih verskih skupnosti za svoje brate. Želimo si dialoga z njimi. Ta pa je mogoč, če bodo tudi oni sprejeli nas.

Frančiškani smo ponosni, da je ustanovitelj reda manjših bratov že pred 800 leti, ko je v družbi prevladovala logika nesprejemanja drugačnosti, s spoštovanjem pristopil in se na robu delte Nila, v Egiptu, miroljubno in dobronamerno pogovarjal s sultanom Al-Kamilom v Damietti. V tem srečanju med sv. Frančiškom in muslimanskim voditeljem na simbolen način prepoznavamo začetke medreligijskega dialoga. Generalni minister reda manjših bratov, Michael A. Perry, je s posebnim pismom povabil frančiškane po svetu, da bi se tega dogodka spomnili z različnimi komemoracijami. Odziv je bil zelo spodbuden. V letu 2019 smo frančiškani po svetu organizirali veliko dogodkov, ki nas spominjajo na srečanje pred osmimi stoletji in nam ovrednotijo medreligijski dialog. Navedimo najpomembnejše dogodke v naši okolici. 
Na prvo mesto moramo brez dvoma postaviti praznovanje v Damietti, kamor je papež Frančišek poslal svojega delegata. Prvega marca 2019 je papežev odposlanec kardinal Leonardo Sandri, prefekt Kongregacije za vzhodne Cerkve, prišel v Egipt in posredoval željo papeža Frančiška, da bi si vsi prizadevali za pospeševanje miru in dialoga. Sveti oče je za to priložnost napisal posebno pismo, $v$ katerem asiškega ubožca imenuje "mož miru«, ki je naučil svoje redovne brate pozdravljati »Gospod naj ti da svoj mir! . Papež je prosil kardinala Sandrija, naj ponese njegov bratski pozdrav vsem, kristjanom in muslimanom. V pismu pa zaželi, da nihče ne bi podlegel skušnjavi nasilja, posebno ne "pod kakršnokoli versko pretvezo, ampak da bi uresničevali načrte dialoga, sprave in sodelovanja, ki vodijo ljudi k bratskemu občestvu« ter širijo mir in dobro v skladu z besedami preroka Izaija: »Narod ne bo več vzdignil meča proti narodu, ne bodo se več učili vojskovanja."V Španiji sta obletnico med 4. in 7. marcem 2019 obeležila Teološki inštitut in Univerza iz Murcie. V Benetkah je Inštitut za ekumenske študije San Bernardini 14. marca 2019 organiziral znanstveni posvet z naslovom A History of Dialogue Beginning with Francis. Devetega aprila je Fakulteta za kanonsko pravo in filozofijo papeške univerze Antonianum v Rimu pripravila konferenco z naslovom Reflecting on Hospitableness Past and Present. Ista frančiškanska univerza je na svojem oddelku za biblične znanosti in arheologijo dogodek v Damietti obeležila 15. maja 2019 v Jeruzalemu. Mednarodna frančiškanska skupnost, ki s svojo prisotnostjo pričuje v Istanbulu, je 19. oktobra 2019 spregovorila o medsebojni prijaznosti (Reciprocal Kindness). Frančiškani v Parizu so od 25. do 26. novembra 2019 razmišljali, ali dogodek pred osmimi stoletji tudi danes prinaša sadove. Tudi slovenski frančiškani smo se priključili praznovanju. Inštitut Stanka Janežiča za dogmatično, osnovno in ekumensko teologijo ter religiologijo in dialog, ki deluje v okviru Teološke fakultete, ter Slovenska frančiškanska provinca sv. Križa sta od 1. do 3. oktobra 2019 v frančiškanskem samostanu na Tromostovju v Ljubljani organizirala znanstveno konferenco "800 let sobivanja«, ki je osvetlila dogodek pred osmimi stoletji in spregovorila o dialogu med kristjani in muslimani v preteklosti in danes. Šestindvajset predavateljev iz osmih različnih držav se je posebno osredotočilo na sodelovanje med frančiškani in muslimani v preteklih osmih stoletjih. Njihovo tridnevno sobivanje, ki je bilo prežeto z debatami in izmenjavo izkušenj, pa je bilo praktičen prikaz medreligijskega dialoga. 
Ko je Cerkev sprejela načelo dialoga v svojo teologijo, se je po eni strani poslovila od težnje po ekskluzivnosti katoliškega nauka v pluralni družbi, po drugi strani pa je dialog za katoličane priložnost in spodbuda k prečiščenju lastne identitete in lastnih temeljev, torej izziv za poglobitev svoje vere. To pa je danes nujno potrebno. Zato je medreligijski dialog koristen za vse. Namen prispevkov v reviji Edinost in dialog je pokazati, da je v slovenskem prostoru medverski dialog živ. Bralcem pa naj članki pomagajo pri uresničevanju dialoga v praktičnem vsakdanjem življenju. 